\section{THE GENDER DIVIDE AGENTS OF CHANGE}

\begin{abstract}
The rights and roles of women in the kingdom are evolving as growing numbers pursue higher education in STEM subjects, at home and abroad. But, for Saudi Arabia's knowledge economy to really thrive, the ranks of women working in science must increase. The Nature Index spoke to five passionate researchers who have taken up the mantle.
\end{abstract}

\section{BY LOUISE SARANT}

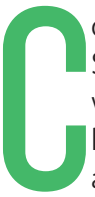
ompared with its neighbours in the Arabian Peninsula, Saudi Arabia was late to invest in the education of girls and women; as recently as 1970, only $2 \%$ of Saudi women were literate, compared to $15 \%$ of men. Today, the kingdom has almost closed the literacy gap, with $92 \%$ of women and 97\% of men able to read and write. Indeed, according to the World Economic Forum, Saudi Arabia is the fifth-most improved country in the world in terms of the education gender gap.

According to the latest available UNESCO statistics, from 2015, women represent $53 \%$ of all Saudi university students studying for bachelor's degrees. In addition, thousands of women pursue degrees in foreign universities as part of a government-funded scholarship programme that guarantees $20 \%$ of its scholarships to female recipients (see page S54). A more permissive culture at KAUST is a departure from many Saudi institutions in terms of dress codes for women, who are also allowed to drive on campus.

Despite the positive steps made in education, Saudi Arabia remains stuck in the lowest echelons of the World Economic Forum's Global Gender Gap report. The biggest gaps can be found in the areas of political empowerment - the country has no women in ministerial positions - and economic participation. Women make up 21\% of the workforce. That's up from just 14\% in 1990, but it still places the country 140 th of 144 countries included in the report. Education and healthcare traditionally absorbed most working females in Saudi Arabia, but since 2005 fields such as banking, retail, design, and IT have gradually opened up to women.

The number of women scientists working in Saudi Arabia remains low. The percentage of female doctoral students is 34\% - 19 percentage points lower than bachelor's students. This 'leaky pipeline' effect, whereby women studying STEM subjects decide not to pursue science further up the career ladder, is especially precipitous in Saudi Arabia, where figures from 2013 show women make up just $23 \%$ of the country's researchers. But the phenomenon is apparent throughout the world - in Japan, for instance, where women make up a similar proportion of doctoral students as in Saudi Arabia, only 15\% of researchers are female.

Statistics, however, can reveal only so much. The Nature Index spoke to five women working in science in Saudi Arabia to get a closer understanding. Some were born and raised in Saudi Arabia; others came to the country later in life. Some are at the beginning of their careers, while others have been recognized with international awards.

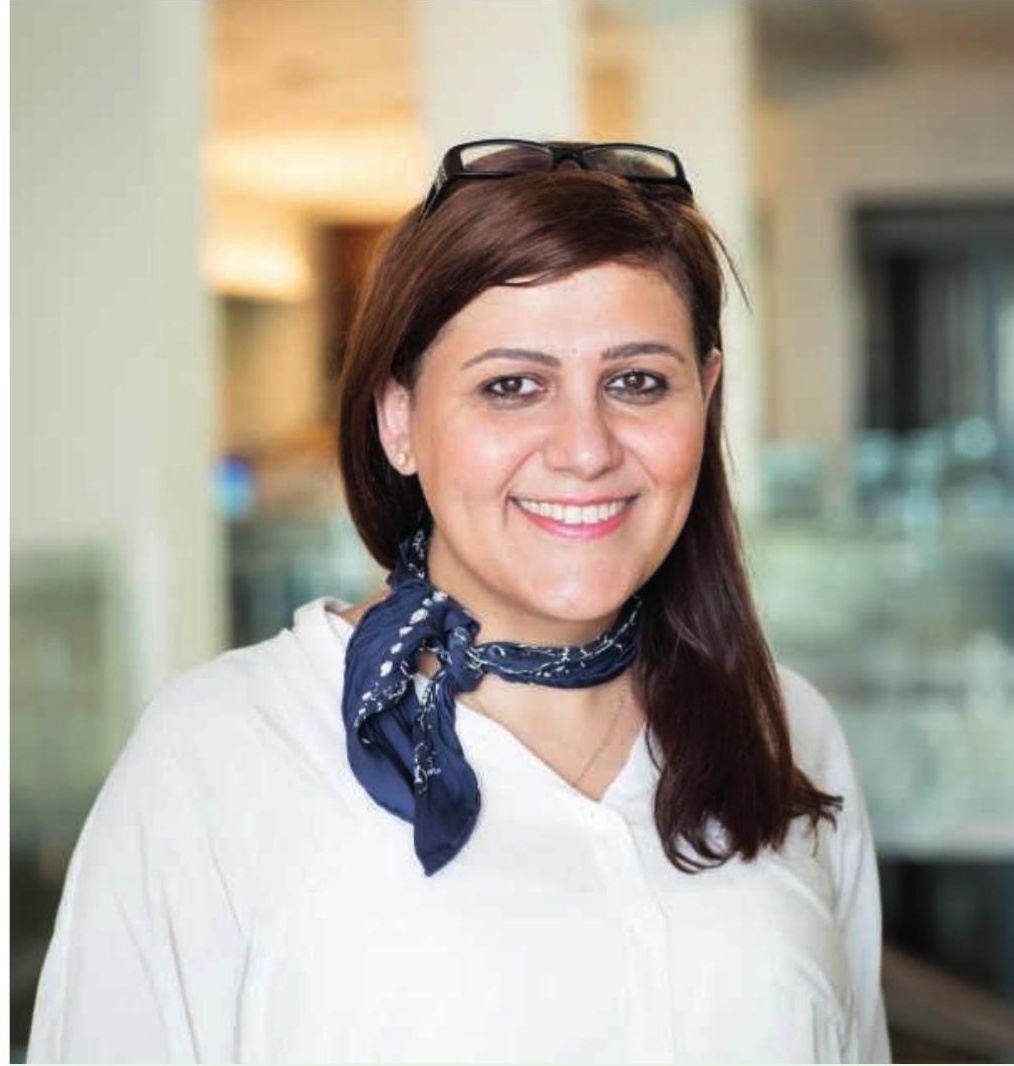

First appearance in the Nature Index: 2014

- No. of papers in the Nature Index (2012-2016): 8

- Most cited paper: 'Mechanised nanoparticles for drug delivery,' Nanoscale, 2009

h-index: 20

\section{STINE BÜCHMANN-MOLLER}

Facilities director, Biosciences and Analytical Core Labs, KAUST.

W hen Stine Büchmann-Møller completed her $\mathrm{PhD}$ in cell and molecular biology at ETH Zurich in 2009, the Danish scientist had no intention of taking the long academic route. "I was technically good and extremely determined to get my foot in the industry," she says. The bleak economic outlook that year severely limited her opportunities, and she found herself accepting a position below her qualifications: as a biomarker scientist for Novartis. But after a year her technical aptitude propelled her to become head of the lab.

Four years into this position, she received a message from a head hunter at KAUST in Saudi Arabia. "KAUST immediately sparked my curiosity," says Büchmann-Møller, who had never heard of the university before. "After visiting the campus, seeing the core labs and having discussions with potential colleagues, I realized that if I worked here, my contributions would make an immediate difference."

Büchmann-Møller's family is rich in strong female role models, and so she does not consider herself a pioneer for her gender. "I am a scientist: I focus on my work, I put my very best into it and so far, it has taken me where I want to be," she says. At KAUST, she became the Biosciences Core Lab director, a position in which she applies her expertise in next-generation sequencing, biomarkers, gene expression and stem 


\section{NIVEEN KHASHAB}

\author{
Associate professor of chemical sciences and \\ engineering, KAUST.
}

A a child, Niveen Khashab had no interest in dolls. Raised in Lebanon by her grandmother after her Saudi mother and Lebanese father separated, the little girl would spend hours wondering about her grandma's collection of pills: how could swallowing these small, colourful capsules make people feel better? As she got older and more acquainted with how drugs were constructed, she "used to inspect the drugs, look at their chemical structures and admire the power of these compounds, once assembled, to cure," says Khashab.

As an undergraduate at the American University of Beirut, Khashab discovered the work of Richard Feynman, the American theoretical physicist credited with inventing the concept of nanotechnology. "Feynman introduced the concept of 'swallowing the doctor' by assembling a smallscale surgical robot that could be swallowed by the patient, and I found it fascinating," says Khashab. She was enthralled by the idea of engineering an atomic scale nanorobot that would target the disease and defeat it.

To obtain a $\mathrm{PhD}$ in this field, her only course of action was to uproot and travel to the United States. "This kind of higher education and professional training was not available in Lebanon then," she explains. After completing her $\mathrm{PhD}$ at the University of Florida in Gainesville, she moved to Northwestern University in Chicago in 2006. It was here that she first heard about KAUST over a cup of coffee with a professor.

"I was utterly intrigued and excited," she says. "I had always wanted to go back to the Middle East, but I thought I would never find a university with the level of resources and high-end labs needed to continue my research." She interviewed for a position and soon moved to Thuwal with her family.

Khashab had visited Saudi Arabia with her mother regularly while growing up, and had no apprehensions moving there to work. "It is home," she says, pointing out that $37 \%$ of all students at KAUST are female, well above the world average for female STEM students (16\%). KAUST is also the only mixed-gender campus in the kingdom - females are allowed to drive and to attend mixed lectures unveiled.

Nonetheless, Khashab is the only female associate professor in KAUST's chemistry department. She heads a lab of 12 postdocs and graduate students in addition to five visiting students working on the design, synthesis and applications of programmable nanomaterials. Khashab's research focuses on biomedical applications of nanotechnology, and she uses nanoparticles to package and deliver drugs straight to the ailing cell while sparing healthy tissues. In this vein, in 2011 she designed a mini-capsule capable of carrying a chemotherapy treatment programmed to destroy cancer cells. Her lab is now testing these devices in animal models.

In March 2017, Khashab received a L'Oréal-UNESCO Women in Sciences Award for her work on innovative materials for drug delivery. "When I got news that I was nominated, I thought it was a little farfetched," says Khashab. "Not because I don't believe in my research, but because I felt so junior compared to the others. This kind of recognition gave me a big push, especially at this stage of my career." The award made people take notice of Khashab's work in nanotechnology, even piquing the interest of people outside biomedicine.

Most recently, it was the oil and gas industry knocking on her lab door. She has come up with intriguing industrial applications based on her research. Nanoparticles, if engineered for the harsh and corrosive environment of oil wells, can aid the exploration of oil deposits. They can also help provide accurate well imaging to show where oil is located and whether two wells are connected.

While Khashab plans to continue her work on industrial sensing and separation applications of her research, her long-term focus is still to build controllable and biodegradable drug delivery vehicles. She believes it could take a decade to reach clinical trials, but she remains intent on pursuing her own version of 'swallowing the doctor.' cell regulation. A key part of her role is to keep abreast of new technology to ensure that the lab's equipment remains cuttingedge. "I convinced KAUST to purchase one of the world's most advanced genome sequencing instrument," she says. "The lab team was worried at first that we did not have enough samples, but now it is running day and night and is the most used instrument in the whole lab."

Büchmann-Møller's role has become increasingly managerial, with 22 full-time employees under her supervision, but she pays attention to the broad range of biological research going on at KAUST. Access to these labs is not restricted to KAUST scientists and staff - other Saudi universities and even industry can benefit from the core labs' facilities, training and services. BüchmannMøller sees this continual circulation of people through the facilities as an opportunity to build important relationships that will ensure the labs' sustainable growth.

In July, thanks to a major reshuffle of the core labs' operational structure, Büchmann-Møller was promoted to the position of facilities director for the Biosciences and Analytical Core Labs. She now oversees a third core lab as well - the newly established Animal Resources Core Lab. "I feel fortunate to have great colleagues and to be in a position to bring them new skills," says Büchmann-Møller, who plans to continue sharing her technical expertise at KAUST for the benefit of the Middle East's research.

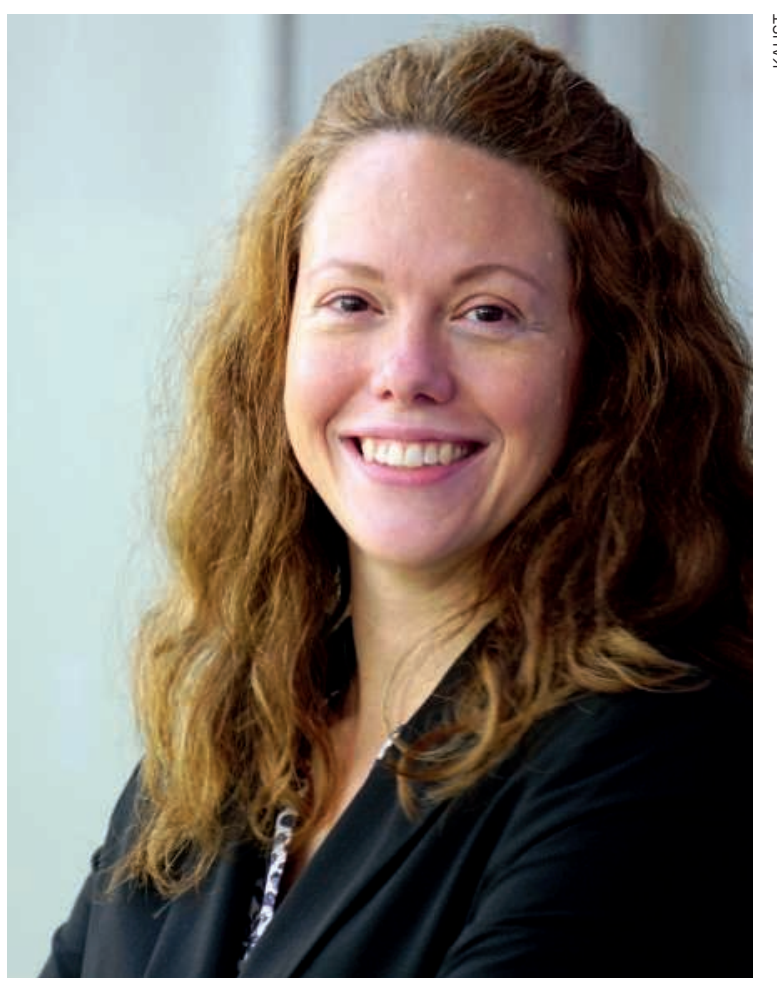




\section{DALAL ALEZI}

Assistant professor, KAU.
- First appearance in the Nature Index: 2015

- No. of papers in the Nature Index (2012-2016): 3

- Most cited paper: 'MOF Crystal Chemistry Paving the Way to Gas Storage Needs: Aluminum-Based soc-MOF for $\mathrm{CH}_{4}, \mathrm{O}_{2}$, and $\mathrm{CO}_{2}$ Storage' Journal of the American Chemical Society, 2015 h-index: 4

and fresh water increasingly energy efficient and cost-effective.

For example, some porous materials can store enough natural gas to power cars over the same distance as a tank of gasoline or diesel in a conventionally fueled vehicle. "MOFs can help foster environmental sustainability," says Alezi.

She is pursuing what has become one of the hottest areas in Saudi science. As the world's largest oil-exporter, Saudi Arabia's petroleum sector represents over half of the kingdom's GDP, and research in this sector has been declared a priority. For the past three years, chemistry has led the physical sciences as a top subject area; the two combined account for $90 \%$ of Saudi Arabia's research output.

Since 2015, Alezi has been the lead author on three papers pu blished in the Journal of the American Chemical Society, under the mentorship of Mohamed Eddaoudi, a leading expert in MOFs and chemical science director of the Advanced Membranes and Porous Materials Research Center. One of her papers describes a MOF that can store methane at low pressures and at room temperature. The processes of separation and purification of gases, fine chemicals and fresh water currently account for $15 \%$ of global energy production, so MOFs have the potential to greatly reduce industrial energy consumption.

Alezi graduated from KAUST this summer, and will soon return to KAU as a lecturer to transfer the knowledge and skills she accumulated during her $\mathrm{PhD}$ years. She plans to foster collaboration and research between the two universities.

The first $\mathrm{PhD}$ holder in her family, Alezi did not have other women in her field to set an example. But, she does not believe that this held her back. "In my experience, inner strength is more important than outside role models," explains Alezi. She has presented her work at conferences abroad and published papers in top-tiered journals. "Maybe I was just born at the right time," she says.

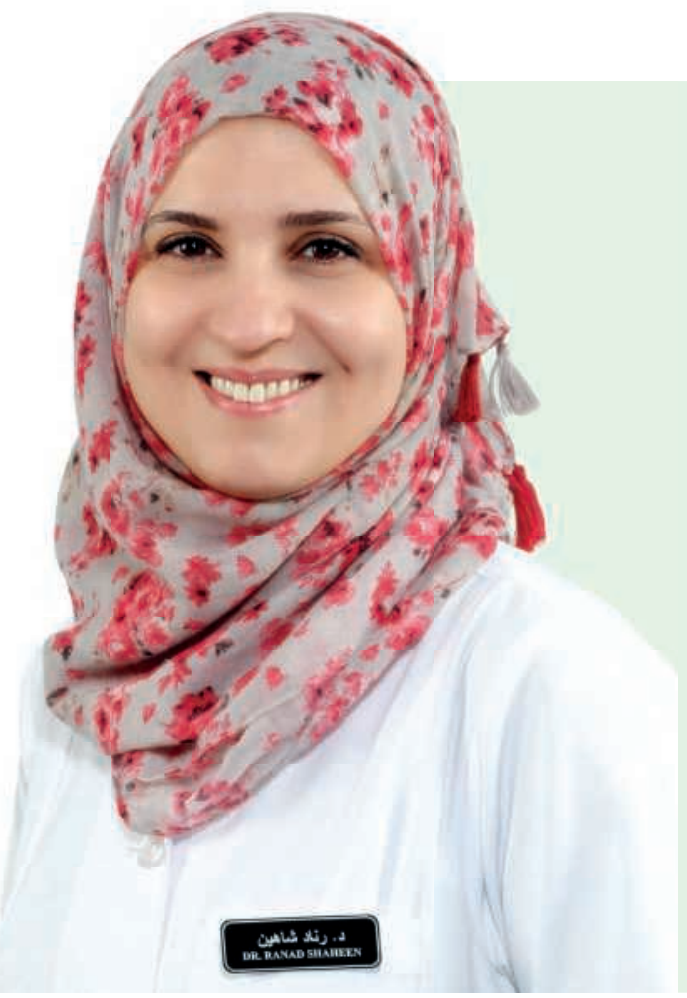

\section{RANAD SHAHEEN}

Senior scientist, Developmental Genetics Unit, King Faisal Specialist Hospital and Research Center.

N ablus-born Palestinian research scientist Ranad Shaheen moved to the Saudi capital in 2005, because her husband landed a job there. Shaheen, who had studied molecular genetics at the University of Otago in New Zealand, and the University of Helsinki in Finland, was not sure what to expect. "I was scared I would hit a wall in my career, given the limited options of research centres here in Saudi Arabia," she says.

Shaheen, who had their third child soon after moving to Riyadh, spent her first three years there writing papers related to her $\mathrm{PhD}$ thesis, which she defended in late 2009. She also used this time to familiarize herself with the kingdom's research needs. The obvious high incidence of congenital and genetic diseases caused by the entrenched traditions of intermarriages in Saudi society seemed an obvious research area.

In 2008, she joined the King Faisal Specialist Hospital and Research Center (KFSH\&RC) as a research associate, and two years later was made a post-doctoral fellow. KFSH\&RC serves as Saudi Arabiass prime research 


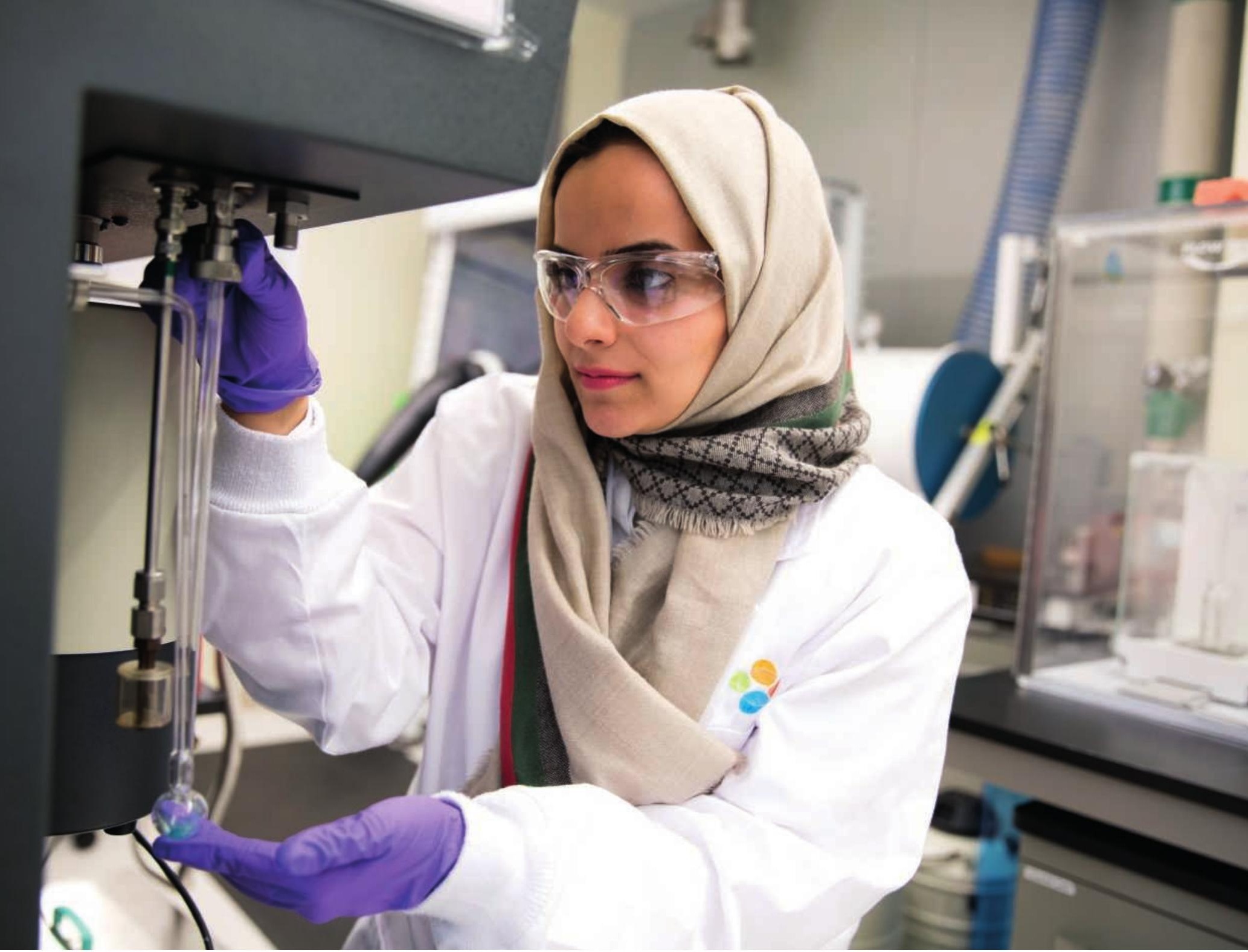


